\title{
Anticipating Xenogenic Pollution at the Source: Impact of Sterilizations on DNA Release From Microbial Cultures
}

\section{OPEN ACCESS}

Edited by:

Stephen Allen Morse,

Centers for Disease Control and Prevention (CDC), United States

Reviewed by:

Wei Zou,

University of Michigan, United States

Siguna Mueller,

Independent Researcher, Kaernten,

Austria

${ }^{*}$ Correspondence:

David G. Weissbrodt

d.g.weissbrodt@tudelft.nl

Specialty section:

This article was submitted to

Biosafety and Biosecurity,

a section of the journal

Frontiers in Bioengineering and

Biotechnology

Received: 18 December 2019

Accepted: 19 February 2020

Published: 13 March 2020

Citation:

Calderón-Franco D, Lin Q, van Loosdrecht MCM, Abbas $B$ and Weissbrodt DG (2020) Anticipating

Xenogenic Pollution at the Source: Impact of Sterilizations on DNA

Release From Microbial Cultures.

Front. Bioeng. Biotechnol. 8:171.

doi: 10.3389/fbioe.2020.00171 David Calderón-Franco, Qingnan Lin, Mark C. M. van Loosdrecht, Ben Abbas and
David G. Weissbrodt*

Department of Biotechnology, Delft University of Technology, Delft, Netherlands

The dissemination of DNA and xenogenic elements across waterways is under scientific and public spotlight due to new gene-editing tools, such as do-it-yourself (DIY) CRISPR-Cas kits deployable at kitchen table. Over decades, prevention of spread of genetically modified organisms (GMOs), antimicrobial resistances (AMR), and pathogens from transgenic systems has focused on microbial inactivation. However, sterilization methods have not been assessed for DNA release and integrity. Here, we investigated the fate of intracellular DNA from cultures of model prokaryotic (Escherichia coli) and eukaryotic (Saccharomyces cerevisiae) cells that are traditionally used as microbial chassis for genetic modifications. DNA release was tracked during exposure of these cultures to conventional sterilization methods. Autoclaving, disinfection with glutaraldehyde, and microwaving are used to inactivate broths, healthcare equipment, and GMOs produced at kitchen table. DNA fragmentation and PCR-ability were measured on top of cell viability and morphology. Impact of these methods on DNA integrity was verified on a template of free $\lambda$ DNA. Intense regular autoclaving $\left(121^{\circ} \mathrm{C}\right.$, $20 \mathrm{~min}$ ) resulted in the most severe DNA degradation and lowest household gene amplification capacity: $1.28 \pm 0.11,2.08 \pm 0.03$, and $4.96 \pm 0.28$ logs differences to the non-treated controls were measured from $E$. coli, S. cerevisiae, and $\lambda$ DNA, respectively. Microwaving exerted strong DNA fragmentation after $100 \mathrm{~s}$ of exposure when free $\lambda$ DNA was in solution (3.23 \pm 0.06 logs difference) but a minor effect was observed when DNA was released from $E$. coli and S. cerevisiae $(0.24 \pm 0.14$ and $1.32 \pm 0.02$ logs differences with the control, respectively). Glutaraldehyde prevented DNA leakage by preserving cell structures, while DNA integrity was not altered. The results show that current sterilization methods are effective on microorganism inactivation but do not safeguard an aqueous residue exempt of biologically reusable xenogenic material, being regular autoclaving the most severe DNA-affecting method. Reappraisal of sterilization methods is required along with risk assessment on the emission of DNA fragments in urban systems and nature.

Keywords: sterilizations, DNA release, xenogenic pollution, DIY biology, antimicrobial resistances 


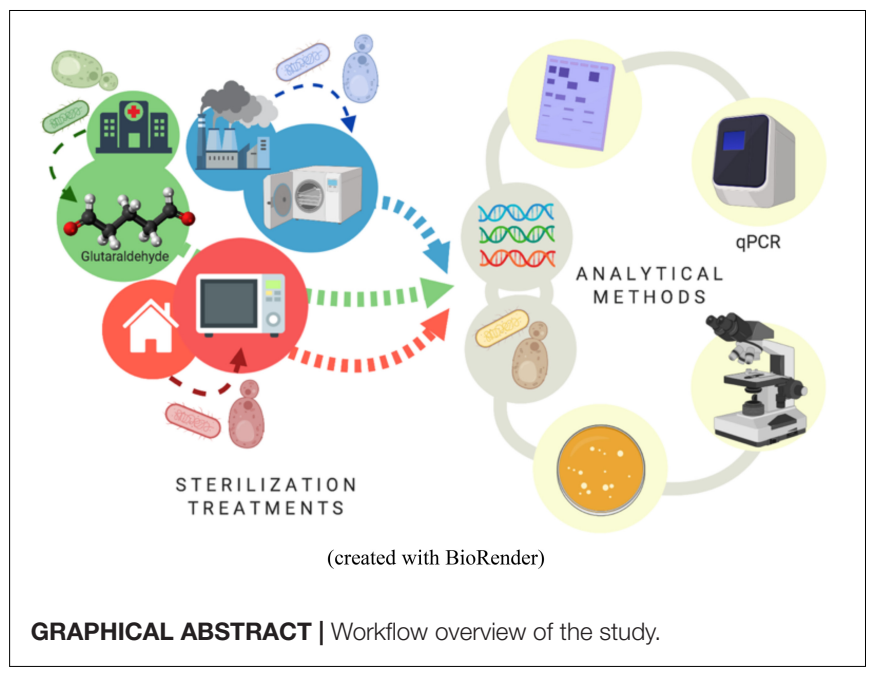

\section{INTRODUCTION}

The rapid development of gene-editing tools together with the broad applications of genetically modified organisms (GMOs) have triggered biosafety concern on the hazard composed by the dissemination of unwanted DNA into the environment after sterilization (Simmon et al., 2004). Concerns have been risen on the emission of xenogenic and mobile genetic elements that may carry antibiotic resistance genes (ARGs) or pathogenicity, and their transport across urban waterways through wastewater treatment plants into nature (Bouki et al., 2013; Miller et al., 2016). Novel CRISPR-Cas technologies propel the engineering of microorganisms out of industry boundary with do-ityourself (DIY) kits available at kitchen table. Uncontrolled, diffuse emission of GMO materials via domestic waste streams could be a threat.

Current sterilization methods are proven to efficiently inactivate microorganisms. However, a key knowledge gap remains on their impact on DNA and its potential release into industrial, clinical, and domestic sewage. Common methods used to treat industrial broths, healthcare equipment and surfaces, and domestic waste primarily involve autoclaving, glutaraldehyde, and microwaving, respectively.

Several studies have shown how DNA present in food products react with different sterilization procedures (Debode et al., 2007; Gryson, 2010; Bergerová et al., 2011). Treatments such as irradiation and autoclaving affect DNA in meat products or edible seeds by decreasing the total DNA content as well as causing DNA fragmentation, degradation and denaturation (Maity et al., 2009; López-Andreo et al., 2012). However, the impact highly depends on the cell type, the sterilization method, and the process conditions.

Temperature, pressure, $\mathrm{pH}$, and sterilization times significantly exert effects on DNA quality. For instance, temperatures over $100^{\circ} \mathrm{C}$ have resulted in significant DNA strand clipping and irreversible loss of secondary structure (Gryson, 2010). Normal autoclaving $\left(121^{\circ} \mathrm{C}\right.$ between 5 and $20 \mathrm{~min}$ ) of food and crops did not impeded it to be available for PCR amplification (Takeshi et al., 2003; Debode et al., 2007; Gryson, 2010).

Microwaving is commonly used in kitchen procedures such as water boiling and food heating (Kim et al., 2008; Fang et al., 2011). It has been suggested to effectively kill bacteria, yeast, and molds on kitchen sponges (Sharma et al., 2009). Microwaves at frequencies of $2450 \mathrm{MHz}$ have been used to sterilize soil due to its ability to inhibit nitrification and sulfur oxidations (Ferriss, 1984; Trevors, 1996; Woo et al., 2000). It has also been used in laboratory settings for pharmaceutical glass vials, culture media, or clinical specimens sterilization (Akşen et al., 2004). The thermal effect mechanism is based on the absorption of microwave heat energy by the cell constituents, which leads to fast vibrations of cell membrane lipids resulting in the emergence of pores (Jankovic et al., 2014). These pores may cause leakage of vital intracellular molecules being able to cause cell death (Jankovic et al., 2014). High temperatures denature cellular biomolecules such as proteins, which may also be a reason of cells lysis (Karni et al., 2013).

Glutaraldehyde is commonly used in industry, research labs and, more specific, in hospitals as a disinfectant on dental and medical instruments, such as endoscopes, and surfaces. Glutaraldehyde has a wide range of biocidal activity against both Gram-positive and Gram-negative bacteria, viruses, and spores (Ballantyne and Jordan, 2001; Sehmi et al., 2016). It is a strong cross-linker that combines with multiple molecular functions such as amino and sulfhydryl groups (Okuda et al., 1991). Glutaraldehyde affects cells by binding to nucleic acids and cross-linking enzymes responsible for oxygen uptake, destroying secondary structures and therefore causing disfunction of cytoplasmic molecules and death of cells (Munton and Russell, 1973).

Here, the model bacterium Escherichia coli and yeast Saccharomyces cerevisiae were used as model organisms to test the impact of autoclaving, microwaving, and glutaraldehyde on the release of DNA from microbial cultures of prokaryotes and eukaryotes, respectively. We elucidated the effects of these three dominant sterilization methods on DNA release, fragmentation, degradation, and amplification capacity on top of cellular inactivation, morphology, and integrity. This incepting work provides first insights to foster the management of the emission of xenogenic pollution.

\section{MATERIALS AND METHODS}

\section{Bacterial and Yeast Strains and Culture Preparations}

A frozen stock of Escherichia coli, DH5a (Cell System Engineering Section, Department of Biotechnology, TU Delft, the Netherlands) was thawed and inoculated into a $300-\mathrm{mL}$ flask containing $200 \mathrm{~mL}$ of Luria-Bertani (LB) cultivation broth. This culture was incubated in a rotary shaker for $6 \mathrm{~h}$ at $37^{\circ} \mathrm{C}, 200 \mathrm{rpm}$, where late $\log$ phase was reached. A frozen stock of Saccharomyces cerevisiae, CEN.PK (Cell System Engineering Section, Department of Biotechnology, TU Delft, The Netherlands) was thawed and inoculated into a 500-mL flask 
containing $200 \mathrm{~mL}$ of yeast extract-peptone-dextrose (YEPD) broth composed of $1 \%$ yeast extract, $2 \%$ peptone, and $2 \%$ glucose/dextrose. This culture was incubated in a rotary shaker for $6 \mathrm{~h}$ at $30^{\circ} \mathrm{C}$ and $200 \mathrm{rpm}$. Samples of $5 \mathrm{~mL}$ at $10^{11} \mathrm{CFU} \mathrm{L}^{-1}$ of cell cultures were prepared for further sterilization treatments.

\section{Physical Sterilization Treatment by Microwaving}

A microwave oven (Bestron Model ER-M18, $2450 \mathrm{MHz}, 230 \mathrm{~V}$, $850 \mathrm{~W}$ ) with a rotating table was used. A sealed glass bottle containing $5 \mathrm{~mL}$ of each microorganism was placed at the center of the rotating table, $20 \mathrm{~cm}$ away from the irradiation source. The microwave was irradiated for a maximum of $30 \mathrm{~s}$ within which different time intervals were taken. For each interval time point $(0,5,10,12,14,16,18,20,25$, and $30 \mathrm{~s})$, different sampling tubes were used to ensure that the treatment duration was continuous. Extra exposure times of 40 to 60, 70, and up to $100 \mathrm{~s}$ were applied to test for the qPCR-ability of the DNA fragments on top of their release from microbial cells. Microwave was set at maximum power mode in order to avoid its automatic on and off switching. Quality controls were performed with pure $1 \mathrm{ng} \lambda \mathrm{DNA} \mu \mathrm{L}^{-1}$ (Thermo Fisher Scientific Inc., Waltham, MA, United States) by irradiating the sample with microwaves for a maximum of $100 \mathrm{~s}$.

\section{Chemical Sterilization Treatment by Glutaraldehyde}

A generic buffer was prepared by mixing $10 \mathrm{~g}$ of sodium bicarbonate $\left(\mathrm{NaHCO}_{3}\right)$ with $90 \mathrm{~g}$ of disodium hydrogen phosphate $\left(\mathrm{Na}_{2} \mathrm{HPO}_{4}\right)$. This buffer mixture was used to adjust the $\mathrm{pH}$ of the glutaraldehyde $\left(\mathrm{C}_{5} \mathrm{H}_{8} \mathrm{O}_{2}\right)$ solution to an alkaline value of 8.0 which ensures the bactericidal activity of glutaraldehyde (Ballantyne and Jordan, 2001). A 2\% (w/w) glutaraldehyde solution $(20 \mathrm{~g} / \mathrm{L}, 0.2 \mathrm{M})$ was prepared and the final $\mathrm{pH}$ of the mixture was set at 8.0 . Volumes of $12 \mathrm{~mL}$ of microorganism suspensions were collected into $15-\mathrm{mL}$ Falcon tubes and were centrifuged at $6000 \times g$ at $4^{\circ} \mathrm{C}$ for $15 \mathrm{~min}$. Afterward, the pellets were resuspended in $12 \mathrm{~mL}$ of $1 \mathrm{xPBS}$ solution ( $\mathrm{pH} 7.4$ ) and placed in an $18^{\circ} \mathrm{C}$ water bath for chemical sterilization. Samples were treated with final glutaraldehyde concentrations of 50, 100, 150, 200, 250, and $300 \mathrm{mg} \mathrm{L}^{-1}$. Each cell suspension was tested out for $20 \mathrm{~min}$. After reaction, cells were washed and resuspended in $1 x P B S$ solution. The same procedure was followed for quality controls performed with pure $\lambda$ DNA at $1 \mathrm{ng} \mu \mathrm{L}^{-1}$.

\section{Thermal Sterilization Treatment by Autoclaving}

Sterilization by autoclaving was tested in an autoclave (SHP Steriltechnik AG, Germany) at $110^{\circ} \mathrm{C}$ and $121^{\circ} \mathrm{C}$ and $1.1 \mathrm{~atm}$ overpressure. The $5 \mathrm{~mL}$ cell suspensions were placed in a $25-\mathrm{mL}$ glass tube inside the autoclave and subjected to sterilization under four different autoclaving default programs (program $\mathrm{P} 1: 110^{\circ} \mathrm{C}$, $20 \mathrm{~min}$; $\mathrm{P} 2: 110^{\circ} \mathrm{C}, 30 \mathrm{~min}$; $\mathrm{P} 3: 121^{\circ} \mathrm{C}, 20 \mathrm{~min}$; and $\mathrm{P} 4: 121^{\circ} \mathrm{C}$, $30 \mathrm{~min}$ ). Same procedure was followed for quality controls with pure $\lambda$ DNA at $1 \mathrm{ng} \mu \mathrm{L}^{-1}$.

All sterilization experiments were done in technical triplicates by treating three individual samples taken from each culture.

\section{Cell Survival}

After sterilization, samples of E. coli were plated on LB agar plates, and samples of $S$. cerevisiae were plated on YEPD agar plates $(100 \mu \mathrm{L})$. E. coli cells were incubated at $37^{\circ} \mathrm{C}$ for $24 \mathrm{~h}$, and $S$. cerevisiae cells were incubated at $30^{\circ} \mathrm{C}$ for $24 \mathrm{~h}$. Plates which contained 30 to 300 colonies were considered suitable for cell counting (Tomasiewicz et al., 1979). Experiments were done in technical triplicates.

\section{DNA Quantification}

After sterilization, $2 \mathrm{~mL}$ of each cell sample was centrifuged at $10000 \times g, 4^{\circ} \mathrm{C}$ for $3 \mathrm{~min}$. After the first centrifugation, $2 \mathrm{~mL}$ of supernatant was collected. To maximize DNA recovery, the residual pellet was washed with $1 \mathrm{~mL} 1 \mathrm{xPBS}$ solution, centrifuged again, prior collecting $1 \mathrm{~mL}$ of supernatant. A total of $3 \mathrm{~mL}$ supernatant was obtained from each sample. Supernatants and pellets were separated and stored at $-80^{\circ} \mathrm{C}$ pending DNA analysis. Intracellular DNA from the pellets was extracted before and after sterilizations with the DNeasy UltraClean Microbial Kit (Qiagen, Germany). The total DNA content of each sample was the combination of the released DNA obtained on the supernatant fraction plus the DNA obtained from the pellet fraction. The amount of DNA released after sterilization was measured from the supernatant by HS dsDNA Qubit assays (Qubit 3.0, Invitrogen, Carlsbad, CA, United States) according to manufacturer's protocol.

\section{DNA Fragmentation}

DNA samples were analyzed by gel electrophoresis with agarose at $1 \%(\mathrm{w} / \mathrm{v})$ (Sigma-Aldrich, Haverhill, United Kingdom) in 1xTAE buffer. DNA was post-stained using SYBR Gold solution (10000x) (Thermo Fisher Scientific, United States) mixed in $1 \mathrm{x}$ TAE buffer (AppliChem, Germany) at 1/10K (v/v). Gels after running were immersed into staining buffer for $40 \mathrm{~min}$ and were further checked with fluorescence imaging system (Syngene, United Kingdom).

\section{Primers Selection for $E$. coli and $S$. cerevisiae and Design for $\lambda$ DNA}

Forward and reverse primers were designed to assess the PCR ability of the released DNA fragments after the different sterilization methods used in this study. All primers were purchased from Sigma-Aldrich (Sigma-Aldrich, Haverhill, United Kingdom). The ßglucuronidase (uidA) gene is a molecular marker from $E$. coli that was evaluated by using uidA forward ( $5^{\prime}$ TGGTAATTACCGACGAAAACGGC-3') and uidA reverse (5'-ACGCGTGGTTACAGTCTTGCG-3') primers (Shimpoh et al., 2017). The TATA binding protein-associated factor (TAF10) gene from S. cerevisiae was evaluated using TAF10 forward ( $5^{\prime}$ ATATTCCAGGATCAGGTCTTCCGTAGC-3') and TAF10 reverse (5'-GTAGTCTTCTCATTCTGTTGATGTTGTTGTTG$\left.3^{\prime}\right)$ primers (Masser et al., 2016). The selection of the gene fragments is not random. The $B$-glucuronidase (uidA) gene has already been reported to efficiently allow for detection and enumeration of $E$. coli while avoiding false positives 
(Silkie et al., 2008). Regarding S. cerevisiae, the TATA binding protein-associated factor TAF10 is a gene, whose expression remains stable independently of growth conditions and strain backgrounds. It makes it a good reference gene for quantitative analysis by qPCR (Teste et al., 2009). For $\lambda$ DNA, an interesting mobile genetic element was found integrated in its genome: the tyrosine recombinase is involved in the mobility of antibiotic resistance gene cassettes on bacterial class 1 integron-integrase gene (intI1). The intI1 gene was therefore assessed by qPCR. This nicely put this study into the context of horizontal gene transfer phenomena and the emerging concern of antibiotic resistant genes emissions and transfer across the water network. The $\lambda$ bacteriophage genome was obtained from GenBank (Wu, 1972; Entry Number J02459.1). Primers targeting the $\lambda$ integrase (intI1) gene were designed in house using SnapGene (GSL Biotech) ${ }^{1}$ : $\lambda$ int forward ( $5^{\prime}$-GTTACCGGGCAACGAGTTGG-3'), $\lambda$ int reverse ( $5^{\prime}$-ATGCCCGAGAAGATGTTGAGC-3') primers.

\section{DNA Extraction and Quantitative PCR (qPCR) Analysis}

The quantification of the $\lambda$ int gene, E. coli uidA gene, and S. cerevisiae TAF10 gene in DNA fragments potentially released after sterilization treatments were analyzed by qPCR (QTower 3, Analytica Jena, Germany). For the standard curve construction, genomic DNA from the model organisms E. coli and S. cerevisiae was isolated using NucleoSpin ${ }^{\circledR}$ Soil (Macherey-Nagel) and Yeast DNA Extraction (Thermo Fisher Scientific Inc., Waltham, MA, United States) kits, respectively. Serial dilutions from $100 \mathrm{ng}$ $\mu \mathrm{L}^{-1}$ down to $10^{-5}$ ng $\mu \mathrm{L}^{-1}$ were used to generate the standard curve. Validation of the standard curve construction was performed by purchasing $0.3 \mu \mathrm{g} \mu \mathrm{L}^{-1} \lambda$ pure DNA (Thermo Fisher Scientific Inc., Waltham, MA, United States). Serial dilution from $1 \mathrm{ng} \mu \mathrm{L}^{-1}$ down to $10^{-8} \mathrm{ng} \mu \mathrm{L}^{-1}$ were used to generate the standard curve. The samples were tested for amplification capacity after sterilization treatments by collecting $1 \mathrm{~mL}$ of sterilized culture and centrifugating it at $15000 \times g$ for $5 \mathrm{~min}$. The supernatant containing released DNA was collected and diluted 1:10 in ultrapure water (Sigma-Aldrich, Haverhill, United Kingdom) prior being used for qPCR analysis. All qPCR reactions were performed in volumes of $20 \mu \mathrm{L}$ composed of $10 \mu \mathrm{L}$ of $\mathrm{IQ}^{\mathrm{TM}} \mathrm{SYBR}^{\circledR}$ Green Supermix (Bio-Rad), $0.2 \mu \mathrm{L}$ of each primer at $50 \mu \mathrm{M}, 8.6 \mu \mathrm{L}$ ultrapure water (Sigma-Aldrich, Haverhill, United Kingdom) and $1 \mu \mathrm{L}$ of template DNA.

The thermal profile selected for the $\lambda$ int gene consisted of $5 \mathrm{~min}$ at $95^{\circ} \mathrm{C}$ hot-start polymerase activation followed by 40 cycles of DNA dissociation at $95^{\circ} \mathrm{C}$ for $30 \mathrm{~s}$, primers annealing at $55^{\circ} \mathrm{C}$ for $30 \mathrm{~s}$ fragment elongation at $72^{\circ} \mathrm{C}$ for $30 \mathrm{~s}$, and terminated by holding at $4^{\circ} \mathrm{C}$.

The thermal profile selected for the E. coli uidA gene consisted of $5 \mathrm{~min}$ at $95^{\circ} \mathrm{C}$ hot-start polymerase activation followed by 40 cycles of DNA dissociation at $95^{\circ} \mathrm{C}$ for $30 \mathrm{~s}$, primers annealing at $57^{\circ} \mathrm{C}$ for $30 \mathrm{~s}$, fragment elongation at $72^{\circ} \mathrm{C}$ for $30 \mathrm{~s}$, and terminated by holding at $4^{\circ} \mathrm{C}$.

The thermal profile selected for the $S$. cerevisiae TAF10 gene consisted of $5 \mathrm{~min}$ at $95^{\circ} \mathrm{C}$ hot-start polymerase activation followed by 40 cycles of DNA dissociation at $95^{\circ} \mathrm{C}$ for $30 \mathrm{~s}$, primers annealing at $55^{\circ} \mathrm{C}$ for $30 \mathrm{~s}$, fragment elongation at $72^{\circ} \mathrm{C}$ for $30 \mathrm{~s}$, and terminated by holding at $4^{\circ} \mathrm{C}$.

\section{Quality Controls}

Different quality controls were used across sterilization experiments and measurements.

Controls for DNA release from cells were produced by beadmilling (or also known as bead-beating) of the bacterial and yeast cultures using the DNeasy UltraClean Microbial Kit. Beadmilled positive controls is considered as an easy and straightforward method for induced intracellular DNA release (Caleb et al., 2019) and non-bead-milled negative controls were included in the analyses.

Controls for DNA degradation were performed by subjecting free-floating $\lambda$ DNA to the same sterilization conditions as the cell cultures. It served as a control as it avoids to worry about the effect of cell breakage and other artifacts, and therefore allowed assessing the effect of sterilization on DNA fragmentation and degradation.

\section{Statistical Analysis}

Statistical analyses were performed with R 3.5.1 (R Foundation for Statistical Computing, 2018) and RStudio ${ }^{2}$. For the analysis and determination of the most effective parameters of the sterilization methods effect on DNA amplification a one-way ANOVA test, that can tolerate skewed or kurtotic distribution data, followed by a post hoc Tukey's honestly significant difference (HSD) test at the 0.05 probability level were performed. Figures were prepared using GraphPad Prism 6 (GraphPad Software, San Diego, CA, United States). The absorbance (or "optical density", OD) of the culture was corrected by assessing the effect of the sterilization methods, assuming homogeneous cultures, thus technical triplicates per biological sample were used.

\section{RESULTS AND DISCUSSION}

\section{Sterilization Methods Inactivated Over 99\% of Living Bacterial and Yeast Cells}

The microwave effect on cell viability (Figure 1A) showed similar end-points but different profiles for both model prokaryotic and eukaryotic microorganisms. For both E. coli and S. cerevisiae, the microwaving performance for $15 \mathrm{~s}$ was sufficient to reduce the number of cells to nearly $10 \%$ of control untreated samples, indicating severe inactivation effect on both microorganisms. Thermal effect is responsible for absorption of microwave energy by cell molecules, producing general heating of the cell (Michaelson, 1974). This causes disarrangement of cell membrane and disruption of cell wall structures by destroying the lipopolysaccharides and peptidoglycan of the cell surface. This results in the emergence of pores, cell aggregations, cytoplasmic proteins aggregation, and changes of membrane permeability (Jankovic et al., 2014; Zeng et al., 2014), explaining why

\footnotetext{
${ }^{2}$ https://www.rstudio.com/
} 

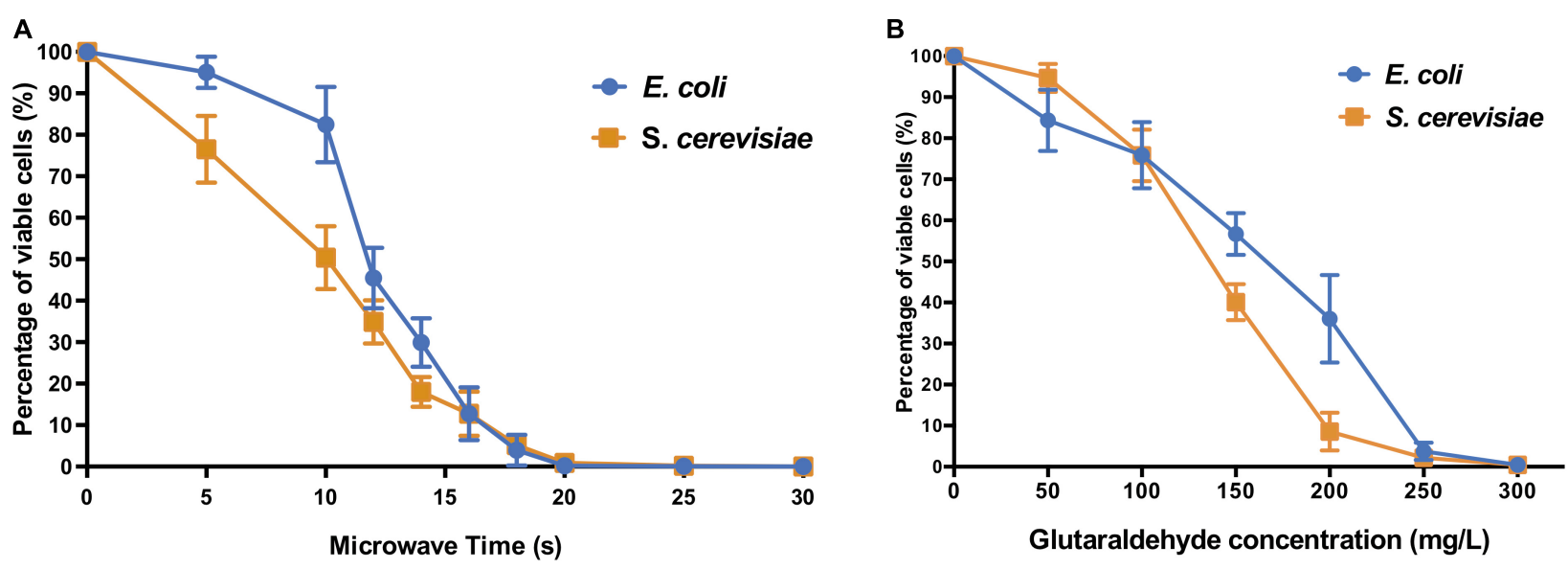

FIGURE 1 | Cell viability of E. coli and S. cerevisiae after (A) different microwave exposure times and (B) glutaraldehyde concentrations. The percentage of viable cells is calculated against corresponding control sample cells (untreated with microwave and untreated with glutaraldehyde, respectively).

biomolecules such as proteins or nucleic acids (Woo et al., 2000) are detected in the extracellular fraction.

The biocidal effects of the increasing dose of glutaraldehyde were shown on both types of microorganism cells (Figure 1B). E. coli and S. cerevisiae both displayed significant reduction of cell viabilities compared to their non-treated control samples. When $300 \mathrm{mg} \mathrm{L}^{-1}$ glutaraldehyde was applied, both microorganisms decreased to a range between $0.1 \%$ to $1 \%$ viable cells when compared to control cultures.

The autoclaving treatment was the most effective on both E. coli and S. cerevisiae (Supplementary Table S1). All autoclaving programs decreased the number of viable cells below the minimum detection limit of $<100 \mathrm{CFU} \mathrm{mL}^{-1}$, thus resulting in nearly zero survivor cells in the autoclaved cell suspension.

\section{Cell Lysis and Aggregation After Autoclaving and Microwaving Whereas Loss of Cell Transparency Is Common After All Sterilization Methods}

Phase-contrast microscopy images showed that untreated E. coli cells were intact and displayed long rod-shaped structures with smooth surface (Figure 2, upper part). Microwave treatment for $10 \mathrm{~s}$ did not affect the overall $E$. coli cell structure as most of the cells maintained their shape (Supplementary Figure S1). After $25 \mathrm{~s}$, cells showed considerable cell debris as well as nonconventional shapes and cell aggregations. Cell transparency was also fully lost after $15 \mathrm{~s}$, becoming dark non-conventional shaped cells compared to the non-treated cells. Short-term microwave treatment preserved cell structure (Supplementary Figures S1E,F) but displayed cell aggregations. The visible damage of $S$. cerevisiae cells emerged 25 s (Supplementary Figures S2D-F), where cell wall destruction resulted in the fusion of $S$. cerevisiae cells into a pool of broken cells. Loss of cell transparency was also observed.

E. coli cells displayed severe structural damages under autoclaving treatment as cells no longer preserved the transparent rod-shaped morphology presented in control samples (Figure 2, middle column). Cells were mostly ruptured into pieces of debris, twisted and shrunk, filled with denatured intracellular molecules (Supplementary Figure S3). For S. cerevisiae, under the first three types of autoclaving programs, cells completely maintained their spherical shape, and hardly any cell debris were observed (Supplementary Figure S4). Cell metamorphosis occurred under the highest intensity of autoclaving (Figure 2, middle column) where cells lost their clear surface layer and started to perform partial fusions.

The most obvious effect of glutaraldehyde fixation on the morphology of both E. coli and S. cerevisiae cells (Figure 2, right column) was the change of cell transparency. The intracellular area of E. coli cells turned black when fixed with glutaraldehyde and for S. cerevisiae, dark spots were present in their cytoplasm. No cell aggregation nor significant cell damage was observed. Cells from both microorganisms still preserved their structural frame even when the highest concentration of glutaraldehyde of $300 \mathrm{mg} \mathrm{L}^{-1}$ was applied (Supplementary Figures S5, S6).

\section{Significant DNA Release Observed Under Microwave and Autoclaving Sterilizations}

The microwave effect on the total DNA released by E. coli was observed after $12 \mathrm{~s}$ and increased abruptly after $16 \mathrm{~s}$ of exposure (Figure 3A). In $S$. cerevisiae cultures, the total DNA released increased constantly from the beginning of the treatment (Figure 3A). Even if $S$. cerevisiae cells released DNA constantly from the start, their cell wall protective ability was higher than the $E$. coli ones: yeasts displayed higher resistance in terms of cell structural collapse and DNA release into the extracellular media. This links to the microscopic pictures presented in Figure 2, where after $20 \mathrm{~s}$ under the microwaves, the $S$. cerevisiae cells preserved their structure whereas the E. coli cells lysed and aggregated (Supplementary Figures S1, S2). Resistance differences also resulted in a lower 


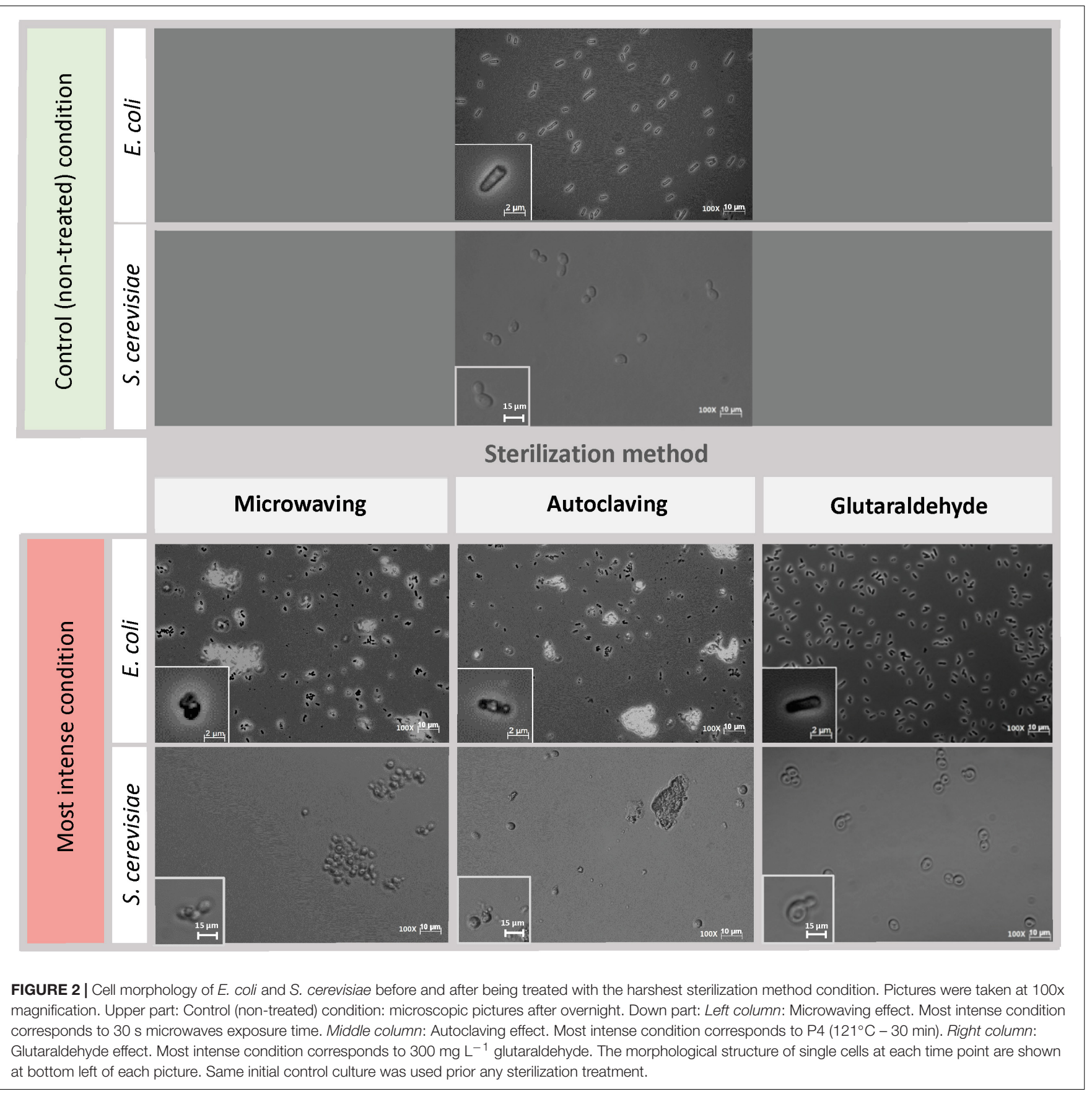

percentage of total DNA released from $S$. cerevisiae at maximum exposure (30 s) of microwave sterilization. Nearly 35\% of total DNA (73.9 ng $\mu \mathrm{L}^{-1}$ ) was released from S. cerevisiae cells at $30 \mathrm{~s}$, in contrast to almost $50 \%\left(59.1 \mathrm{ng} \mu^{-1}\right)$ from $E$. coli (Supplementary Figures S7A-D).

All types of autoclaving led to considerable amount of DNA released to the medium from both microorganisms (Figure 3B). Different autoclaving programs caused 65\% (P1) to nearly $80 \%$ (P4) of total DNA leakage from E. coli cells while lower amounts of total DNA, 53\% (P1) to 65\% (P4), were observed on S. cerevisiae cultures (Supplementary Figure S8).
When an increasing amount of glutaraldehyde was applied from 0 to $300 \mathrm{mg} \mathrm{L}^{-1}$, the percentage of total DNA released to extracellular medium (Figure 3C) stayed either steady at $0.6 \%$ for S. cerevisiae or fluctuating from 0.4 to $0.9 \%$ for E. coli. Almost all the DNA from both microorganisms remained intracellularly (Supplementary Figures S7E-H). Glutaraldehyde displays a protective effect against cell lysis (Azeredo et al., 1999; D'Souza and Marolia, 1999) and strongly inhibits autolytic and proteolytic processes (Flores et al., 1996). This explains why DNA was not released into the extracellular fraction. Glutaraldehyde does perform cross-linking reactions with compounds present in the 

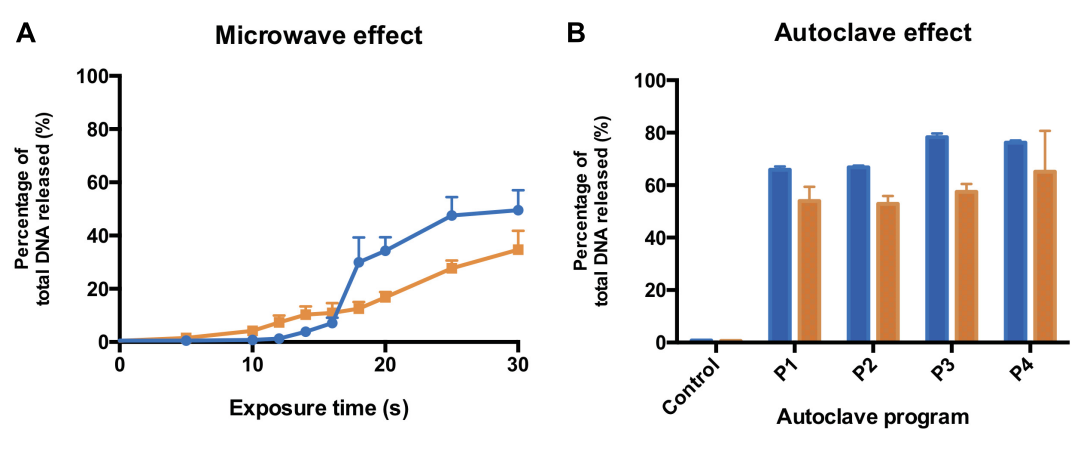

C Glutaraldehyde effect

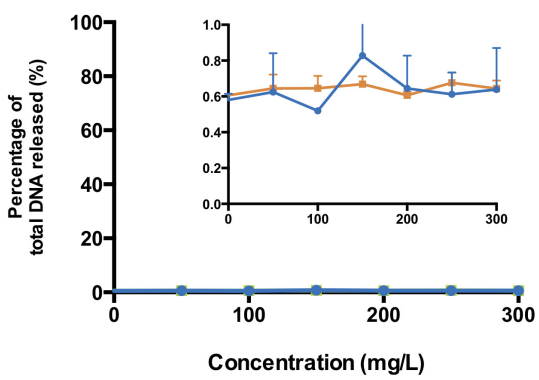

E. coli

S. cerevisiae

FIGURE 3 | Total DNA released from E. coli and S. cerevisiae treated with (A) different microwave exposure times, (B) different autoclave programs and (C) different glutaraldehyde concentrations. The percentage shows the ratios of the amount of DNA (dsDNA) released in the supernatant against the total amount of DNA (released and remained combined). Autoclave programs: P1 (110 $\mathrm{C}-20 \mathrm{~min}), \mathrm{P} 2\left(110^{\circ} \mathrm{C}-30 \mathrm{~min}\right), \mathrm{P} 3\left(121^{\circ} \mathrm{C}-20 \mathrm{~min}\right)$ and P4 (121 $\left.{ }^{\circ} \mathrm{C}-30 \mathrm{~min}\right)$. Control (non-treated cells). $100 \%$ correspond to $59.1 \mathrm{ng} \mu \mathrm{L}^{-1}$ and $73.9 \mathrm{ng} \mu \mathrm{L}^{-1}$ for $\mathrm{E}$. coli and S. cerevisiae, respectively.

cell outer layers, thus negatively altering the permeability and transportability of cell membranes (Munton and Russell, 1973; Maillard, 2002; Sehmi et al., 2016). Our observations show that this chemical exposure time $(20 \mathrm{~min})$ is enough to inactivate cells and prevent the transport and release of nucleic acids across membranes.

\section{Long Microwave Exposures and All the Autoclave Programs Showed Severe DNA Damage}

The DNA fragments of the untreated E. coli control sample displayed on agarose gel have a size above $10 \mathrm{~kb}$. When cells were treated with increasing duration of microwave, the intracellular DNA bands were less intense and displayed a slight decline gradient of DNA sizes, trailed by smears at different degrees (Supplementary Figure S9A). For S. cerevisiae (Supplementary Figures S9C,D), the DNA extracted from untreated cells showed multiple bands of various lengths from approximately $400 \mathrm{bp}$ to over $10 \mathrm{~kb}$. After $25 \mathrm{~s}$ of microwaving, no clear bands but smears were displayed on the gels. An exposure of $30 \mathrm{~s}$ resulted in elimination of $S$. cerevisiae visible bands in the intracellular fraction (Supplementary Figure S9C). The fragmentation patterns in E. coli matched the measurements of DNA content (Figure 3A) for which a significant amount of DNA was released from 18 s onward (Supplementary Figure S9B). An increasing gradient of the free-floating DNA intensity on the gel from S. cerevisiae (Supplementary Figure S9D) fitted to the gradual DNA release (Figure 3A).

In contrast to microwaving, extracellular and intracellular DNAs from both microorganisms were more highly fragmented and/or degraded when heat and pressure (1.1 atm overpressure) were applied (Figure 3B), displaying smears on agarose gels (Supplementary Figures S10A-D). The highest autoclaving program $\left(121^{\circ} \mathrm{C}, 30 \mathrm{~min}\right)$ showed the strongest DNA damage and release when compared with controls and other conditions (Supplementary Figures S5A-C, lanes 5). Even when the harshest autoclaving was applied, intense bands of DNA were still observed on the agarose gels. The degree of intracellular DNA degradation was lower than the released DNA after autoclaving treatment, presumably due to the protection of cells on its cytoplasmic DNA against external damage (Espy et al., 2002; Elhafi et al., 2004; Simmon et al., 2004). A possible reason why $E$. coli shows higher resistance to stress when compared to $S$. cerevisiae, apart from their higher surface to volume ratio, could be its polyunsaturated fatty acids (PUFAs) composition in their membrane: they contribute to cell membrane flexibility. PUFAs level in S. cerevisiae membranes are low or inexistent when growing under normal conditions (Kajiwara et al., 1996; Uemura, 2012) whereas in E. coli cells are higher (Shokri and Larsson, 2004).

Intracellular DNA of $E$. coli treated with the highest concentration of glutaraldehyde resulted in a smear with high fragment lengths (Supplementary Figure S11A, lane 7). Intracellular genomic DNA on $S$. cerevisiae did not result in the absence of DNA bands but a decrease of the band intensity (Supplementary Figure S11C, lane 7). The extracellular DNA from both types of microorganisms (Supplementary Figures S11B-D) showed similar patterns containing short DNA fragments from $<100 \mathrm{bp}$ to $>200 \mathrm{bp}$, same as their corresponding untreated controls. The presence of residual extracellular DNA primarily results from the natural DNA release of microbial cells even before application of glutaraldehyde (Kloos et al., 1994).

\section{Autoclaving Was the Most Effective in Compromising PCR-Ability}

The amplification efficiency of selected genes was assessed after sterilization by qPCR. Differences of $\log _{10}$ number of DNA copies per $\mathrm{mL}$ between bead-milled control samples (autoclaving and microwaving) or non-bead-milled control samples (glutaraldehyde) and treated samples gave an insight on the DNA integrity after sterilization. For autoclaving and microwaving, $\log _{10}$ values close to the control indicated a high number of amplifiable DNA sequences available in the sample. This meant that DNA was not degraded enough and maintained 
its integrity. For glutaraldehyde, values close to the non-beadmilled samples indicated no DNA release nor an effect on PCR ability. Glutaraldehyde treatment did not release any significant amount of DNA in the supernatant (Figure 3C). For this reason, a non-bead-milled control was added. It was important to know if the amount of DNA released after glutaraldehyde treatment was similar to non-sterilized samples, where culture supernatant was basically assessed by qPCR without being sterilized. This gave an idea about the number of DNA copies available that could have been released by some passive release mechanisms or some basal cells decay during the overnight culture.

Bead-milling was the method of choice to release most of the intracellular DNA and is conventionally used for DNA extractions from microbial samples, but sometimes it is possible that the sterilization experiments showed higher release. It was expected with the mechanical disruption that DNA was released (but potentially not denatured). With the sterilizations here applied, DNA was expected to be released and potentially denatured and thus less PCR-able. Controls are not unique for all the cases: controls were included simultaneously to sterilized samples.

For qPCR analysis, the amplified DNA fragments should not exceed 200-250 bp. This is a relatively short DNA fragment size. It was hypothesized that qPCR measurements will highlight whether the DNA released after sterilization was strongly damaged. A high fragmentation of genomic DNA would result in DNA fragment sizes below 200-250 bp, allowing to see an effect in loss of PCR ability.

In E. coli cultures, no effect on PCR ability was observed when DNA was released from cells after microwaving. There were higher initial (5 s) $\log _{10}$ differences with the bead-milled control sample $(0.77 \pm 0.02)$ values due to lack of DNA available on the extracellular fraction (6.79 $\log _{10}$ gene copies $\left.\mathrm{mL}^{-1}\right)$. DNA was exponentially released after $25 \mathrm{~s}(7.22 \pm 0.07$ $\log _{10}$ gene copies $\mathrm{mL}^{-1}$, Figure 4A), and significantly released after $70 \mathrm{~s}\left(7.84 \pm 0.01 \log _{10}\right.$ gene copies $\left.\mathrm{mL}^{-1}\right)$. After $100 \mathrm{~s}$ exposure, DNA was released from cells $\left(7.81 \pm 0.08 \log _{10}\right.$ DNA copies) as its number of sequences even got higher than the control values $\left(7.56 \pm 0.01 \log _{10}\right.$ DNA copies) but its PCR ability was not compromised. Regarding autoclaving, a signal was observed even after P3 and P4 programs were applied (Figure 4C): $1.28 \pm 0.11$ and $1.16 \pm 0.04 \log _{10}$ gene copies per $\mathrm{mL}$ difference with the bead-milled control, respectively. Glutaraldehyde did not have a significant effect on the PCR ability (Figure 4E) mainly because samples treated with glutaraldehyde did not release DNA (Figure 3C). In this case, the nonbead-milled control contained a relatively high number of gene copies in the supernatant, which anyway corresponded to similar values when different glutaraldehyde concentrations were applied. Overall, the qPCR background was relatively high for both the controls and the samples (Figure 4E). An analysis of variance (ANOVA) on these scores yielded significant variation among autoclaving and microwaving treatments but not glutaraldehyde treatments. When compared with the beadmilled control sample, $F=10245.62$ and $F=149.09, p<0.0001$ were observed for autoclaving and microwaving, respectively (Supplementary Table S2). A post hoc Tukey test showed that all the autoclaving treatments (P1, P2, P3 and P4) and control belonging group differed significantly at $p<0.05$ (table not shown) on the PCR-ability of release DNA from E. coli cultures. Regarding microwaving, the Tukey test showed significant $(p<0.05)$ differences from 60 to 100 s exposure times.

In $S$. cerevisiae cultures, DNA was released in a constant trend when microwaving meaning that lower amounts of DNA were available in the supernatant per time unit. This balance of DNA release seems to be proportional to degradation over time. This was reflected in Figure 4B, where constant values around $1.5 \log _{10}$ differences are observed over time. A decrease of $4.78 \pm 0.18 \log _{10}$ DNA copies per $\mathrm{mL}$ at $60 \mathrm{~s}$ was observed but went up to $5.11 \pm 0.2 \log _{10}$ DNA copies per $\mathrm{mL}$ at $70 \mathrm{~s}$. After the longest microwaving exposure time of $100 \mathrm{~s}$, the number of amplicons increased $\left(5.4 \pm 0.02 \log _{10}\right)$ indicating no significant effect on DNA integrity (i.e., can be amplified by qPCR). DNA release pattern and PCR ability from S. cerevisiae differ drastically from the exponential released observed in E. coli cultures (Figure 4A). After autoclaving, qPCR still detected some sequences (1.62 $\pm 0.15 \log _{10}$ difference) even after the most intensive programs (P4: $121^{\circ} \mathrm{C}, 30 \mathrm{~min}$, Figure 4D). However, P3 $\left(121^{\circ} \mathrm{C}, 20 \mathrm{~min}\right)$ resulted in lower amplifiable DNA sequences (2.08 $\pm 0.03 \log _{10}$ difference). As observed in $E$. coli cultures, glutaraldehyde did not have a significant effect on DNA PCR ability mainly because samples released non-detectable levels of DNA (Figure 4E). It was observed that DNA found in supernatant after glutaraldehyde treatment was at a similar level to the negative control, confirming that DNA was not released and thus, not amplified (Figure 4F). An ANOVA on these scores yielded significant variation among autoclaving treatment but not after microwave and glutaraldehyde treatments. When compared with the bead-milled control sample, $F=137.77, p<0.0001$ were observed for autoclaving (Supplementary Table S2). Tukey test showed that all the autoclaving treatments (P1, P2, P3, and P4) and control belonging group differed significantly at $p<0.05$ (table not shown) on the PCR-ability of release DNA from $S$. cerevisiae cultures. Regarding microwaving and glutaraldehyde, no significant $(p>0.05)$ mean differences were observed supporting the low effect of these methods on PCR ability. High temperature in combination with high pressure massively degrades DNA even in a short period of time of $5 \mathrm{~min}$ (Karni et al., 2013).

Some studies have shown that dry autoclaving at $100^{\circ} \mathrm{C}$ for $10 \mathrm{~min}$ has been already sufficient to result in not amplifiable DNA from soybean (Bergerová et al., 2011). However, genomic DNA amplification has been observed at different autoclaving times (from 10 to $40 \mathrm{~min}$ ) out of cultures of Pseudomonas aeruginosa, Salmonella Nottingham, and Escherichia coli. Collectively, this suggests a potential risk made by residual genomic DNA after inactivation of microbial cells due to potential horizontal gene transfer phenomena (Yap et al., 2013). Little is known on the amplification capacity of free DNA after autoclaving treatment of industrial model organisms, being a source of xenogenic contamination out of industries and laboratories. 


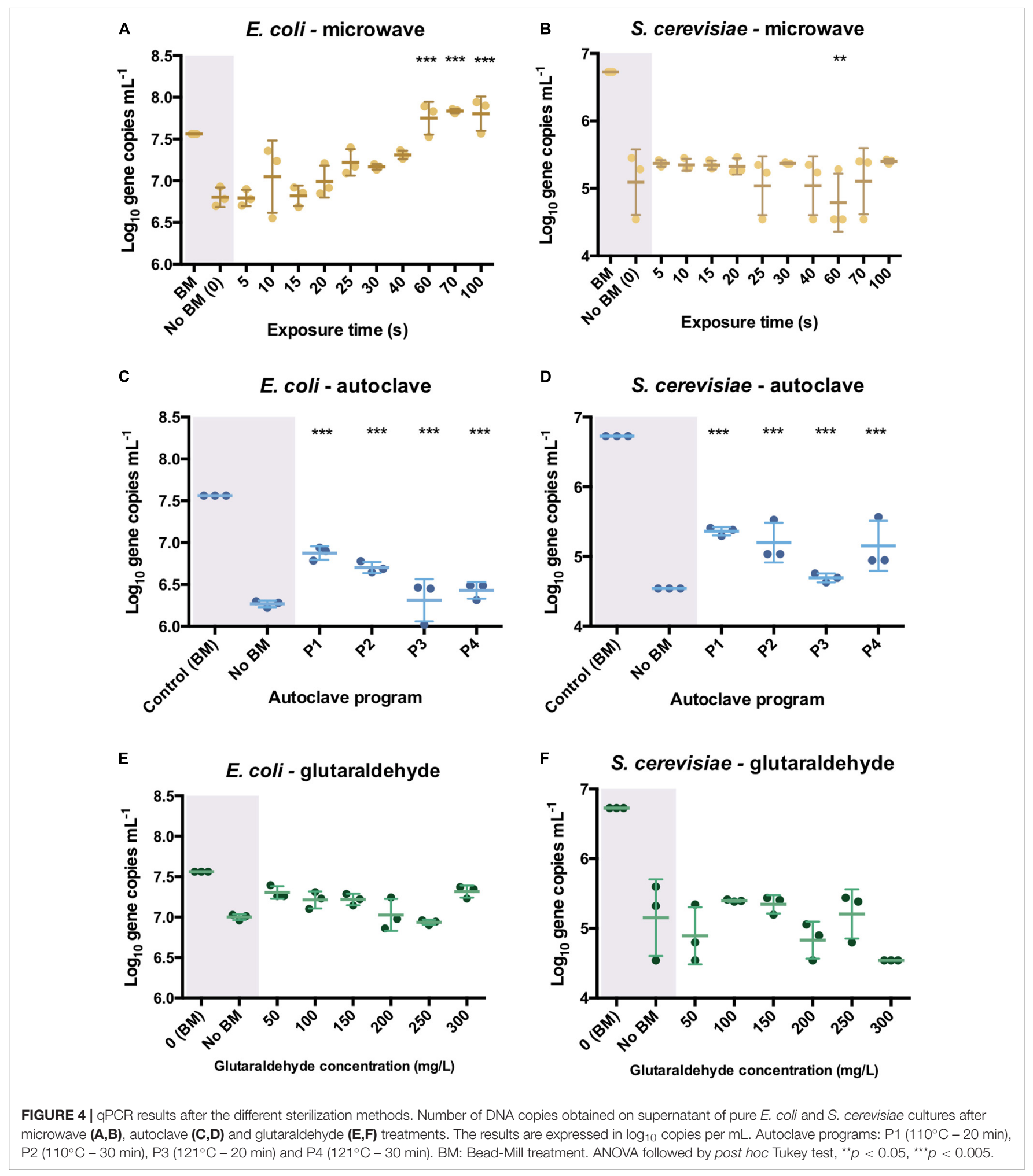

DNA fragmentation was experienced with both autoclaving and microwaving. Although fragmented, the DNA pieces could still be amplified to some extent by qPCR. The sterilization exposure time was sufficient to break the cells, to release and to fragment, while not sufficiently long to lead to a DNA residue degraded enough to affect its PCR ability. For autoclaving and microwaving we can postulate the following mechanistic steps in the sterilization process: (i) cells 

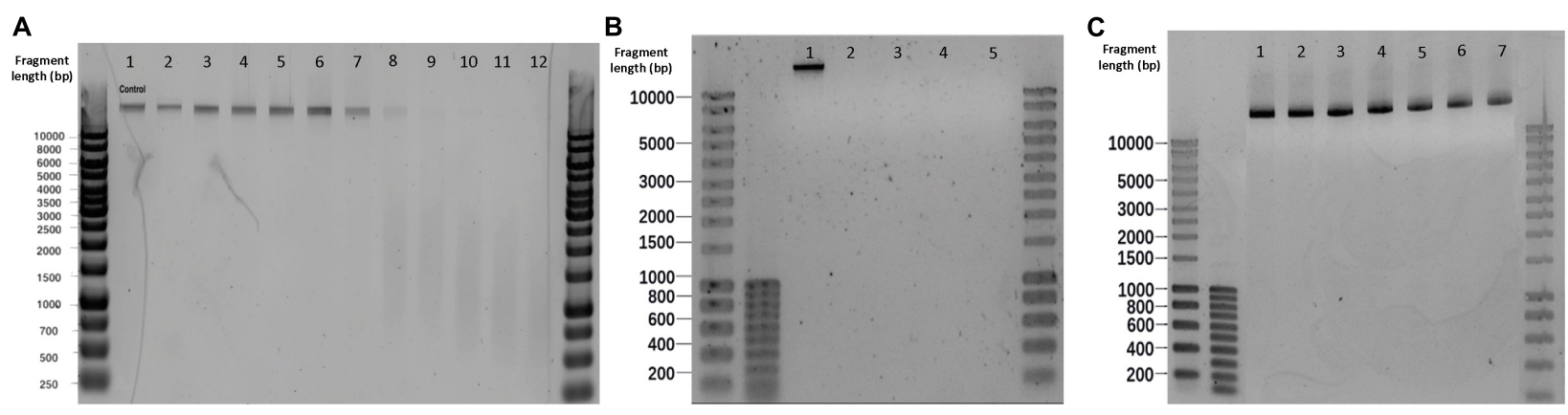

FIGURE 5 | Effect of different sterilization methods on $\lambda$ DNA fragmentation. (A) Microwaving. Lanes 1-12 correspond to 0, 5, 10, 15, 20, 25, 30, 40, 50, 60, 70, 100 s microwave exposure time, respectively. (B) Autoclaving. Lanes 1-5 correspond to control, P1, P2, P3, and P4, respectively. Autoclave programs: P1 (110 $\left.{ }^{\circ} \mathrm{C}-20 \mathrm{~min}\right), \mathrm{P} 2\left(110^{\circ} \mathrm{C}-30 \mathrm{~min}\right), \mathrm{P} 3\left(121^{\circ} \mathrm{C}-20 \mathrm{~min}\right)$ and P4 (121 $\left.{ }^{\circ} \mathrm{C}-30 \mathrm{~min}\right)$. (C) Glutaraldehyde. Lanes 1-7 correspond to 0,50, 100, 150, 200, 250 and $300 \mathrm{mg} \mathrm{L}^{-1}$ glutaraldehyde, respectively.

breakage, (ii) DNA release, (iii) DNA fragmentation, (iv) DNA degradation.

\section{Quality Test Experiments Using Autoclave and Microwave Treatments Showed Faster Pure DNA Degradation Patterns When Compared to Pure Cultures}

The different sterilization treatments were tested out in vitro on pure phage $\lambda$ DNA and analyzed by gel electrophoresis to assess afterward their effect on free extracellular DNA.

All the autoclaving programs applied on pure $\lambda$ DNA reflected neither visible bands nor smears on gel electrophoreses, meaning that complete degradations of naked $\lambda$ DNA occurred (Figure 5B). DNA was not visible for SYBR-Gold staining. In contrast with the DNA treated by autoclaving in vivo (Supplementary Figure S10), where intracellular DNA migrated slower and displayed higher fragment length than released DNA. The disappearing of $\lambda$ DNA treated with high temperature and pressure manifested the protection of DNA by cells against damage. Slight increased pressure and temperatures decay the primary structure of double-strand DNA by hydrolyzing its chemical bonds (Masters et al., 1998). This significantly affects the DNA stability and causes DNA fragmentation. This is remarkable with free DNA and was confirmed by the autoclaving of pure free $\lambda$ DNA, where gels did exhibit severe DNA fragmentation (Figure 5B).

An exposure of $30 \mathrm{~s}$ to microwaves was not sufficient to cause degradation and fragmentation to free pure $\lambda$ DNA: the band obtained after treatment (Figure 5A. Lane 7) remained identical to the untreated template (Figure 5A. Lane 1). At $40 \mathrm{~s}$, the DNA band lost its intensity, resulting in a smear with lower fragment lengths. After $60 \mathrm{~s}$, the band disappeared and completely turned into a smear. In comparison with the results in microbial cultures (Supplementary Figure S9), the phage $\lambda$ DNA treated with the same duration of microwaving resulted in slower migrations across the gel than the DNA released from E. coli and $S$. cerevisiae cultures. Non-thermal factors are all of the effects that are not caused by an increase of temperature, especially when low frequencies and intensities are applied (Belyaev et al., 1992). Belyaev (2005) has shown that radiation-induced DNA breaks could not be repaired after non-thermal microwave exposure. This effect inhibits DNA repair being a plausible cause for cells inactivation. When moving from the cellular to the DNA level, microwaves can destroy DNA by denaturation, degradation, and fragmentation (Fang et al., 2011; Yang and Hang, 2013).

No DNA degradation nor fragmentation could be observed when increasing glutaraldehyde concentrations (Figure 5C).

\section{Pure $\lambda$ DNA Amplification Efficiency Decreased Under Long Microwave Exposures and All Autoclaving Programs}

The qPCR of the pure bacteriophage $\lambda$ int gene was used to evaluate the extracellular DNA capacity to be amplified right after the different sterilization methods.

All the autoclave treatments were shown to significantly affect the PCR ability of the $\lambda$ DNA (Figure 6B) notably when applying program $\mathrm{P} 4\left(121{ }^{\circ} \mathrm{C}, 30 \mathrm{~min}\right)$ when compared with the nontreated $\lambda$ DNA control. Differences of $2.56 \pm 0.61,3.04 \pm 1.22$, $4.75 \pm 0.24,4.96 \pm 0.28$ logs were observed for P1, P2, P3 and $\mathrm{P} 4$ versus the control, respectively. An ANOVA on these scores yielded significant variation among autoclaving treatments when compared with the control, $F=11.41, p<0.001$ (Supplementary Table S3). A Tukey test showed that all the autoclaving treatments (P1, P2, P3 and P4) and control belonging group differed significantly at $p<0.05$ (table not shown) on the PCR-ability of $\lambda$ DNA.

It took around 30 to $50 \mathrm{~s}$ to detect high concentrations of DNA in the extracellular fraction and around more than $100 \mathrm{~s}$ to start seeing a decay in PCR ability. From the combination of experiments with microbial cultures and free-floating $\lambda$ DNA, exposure time longer than $100 \mathrm{~s}$ would be necessary to inactivate cells, release DNA, and fragment it. Otherwise, no effect will be observed on DNA integrity.

Similar results were observed when samples were exposed for over $40 \mathrm{~s}, 0.5 \pm 0.09$ logs difference, under microwaves (Figure 6A). Significant variation among microwaving 

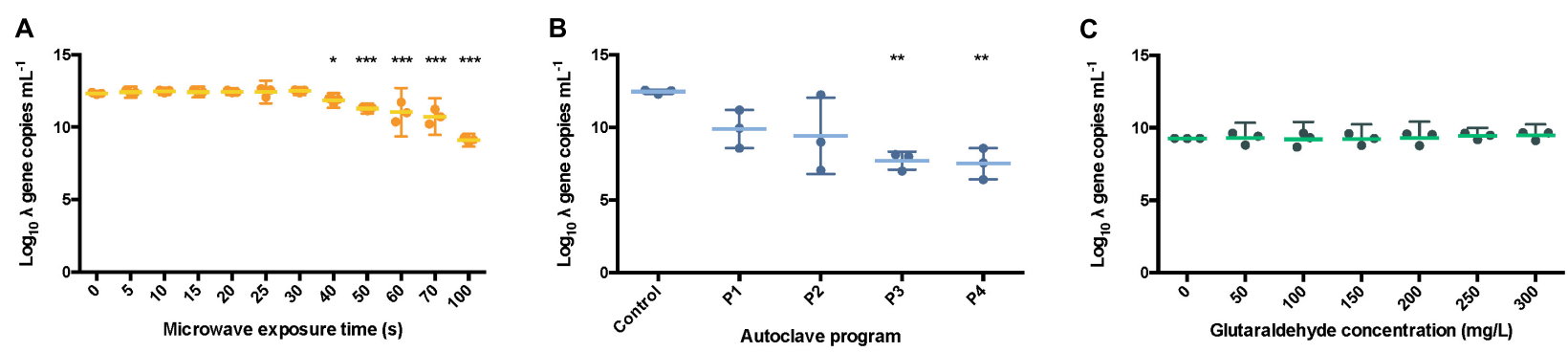

FIGURE 6 | Number of int copies from $\lambda$ DNA available after microwaving (A), autoclaving (B) and treating with glutaraldehyde (C). The results are expressed in $\log _{10}$ copies per $\mathrm{mL}$. The middle line represents the mean, and the whiskers represent the $95 \% \mathrm{Cl}$. Autoclave programs: $\mathrm{P} 1\left(110^{\circ} \mathrm{C}-20 \mathrm{~min}\right), \mathrm{P} 2\left(110^{\circ} \mathrm{C}-30 \mathrm{~min}\right.$ ), P3 (121 $\mathrm{C}-20 \mathrm{~min})$ and P4 (121 $\left.{ }^{\circ} \mathrm{C}-30 \mathrm{~min}\right)$. Control: non-sterilized samples corresponding to $1 \mathrm{~g} \mathrm{~L}^{-1} \lambda$ DNA.

treatments when compared with the control, $F=26.04$, $p<0.0001$ (Supplementary Table S4) was observed. Moreover, a Tukey test showed that exposure times over $60 \mathrm{~s}, 1.31 \pm 0.17$ logs difference, differed significantly at $p<0.05$ (table not shown). This is supporting the clear band loss after $60 \mathrm{~s}$ during gel electrophoresis (Figure 5A). At $100 \mathrm{~s}$, a difference of $3.23 \pm 0.06$ logs with the untreated control sample was observed.

Under microwave treatment, DNA damage on pure $\lambda$ DNA was more severe than in DNA released from microbial cells. Although the DNA of E. coli (approximately $4 \mathrm{Mb}$ ) and $S$. cerevisiae (approximately $12.1 \mathrm{Mb}$ ) harbors significant differences in the size of their genomes, which are also both larger than the size of $\lambda$ DNA (48 kb) (Blattner et al., 1997; Engel et al., 2014), the main reason resided in the contact time with the sterilization treatments.

The sterilization processes by microwaving and autoclaving conducted on cells were described to involve 4 different steps from cell breakage to DNA release, DNA fragmentation, and DNA degradation. In most of experiments performed on cell cultures, the contact time was not long enough to enable degradation of DNA beyond its release. In the case of the free DNA control, $\lambda$ DNA was directly exposed from start to the sterilization treatments. $\lambda$ DNA was therefore longer in contact with the sterilization conditions than the DNA released from cell. This longer exposition led to degradation of $\lambda$ DNA to some extent.

In addition, when cells are treated with microwaves, temperature in highly concentrated cell suspensions increased faster than in low cell concentration suspensions (Zeng et al., 2014). Hence, the DNA released from suspensions of E. coli and $S$. cerevisiae could end up with a higher temperature compared to the pure $\lambda$ DNA solution when treated with the same duration of microwave, accelerating DNA degradation. However, even if DNA in suspension could end up with higher temperatures, first it should be released before being nakedly exposed to the environmental conditions of the system.

In our study, a first question targeted whether DNA was released: this was confirmed by Qubit results (Figure 3A) and gel electrophoresis (Supplementary Figure S9). A second question targeted whether the integrity of DNA was impacted during the treatments, which was checked by qPCR. The summary of the microwave effect on microbial cultures (Figure 3A;
Figures 4A,B) and on naked pure DNA (Figures 5A, 6A) does provide important information for bench-top practice if microwave is the desired method to sterilize your microbial culture. Our results suggest that an exposure time of more than $100 \mathrm{~s}$ is needed under our experimental conditions to efficiently inactivate microorganisms and degrade the potentially harmful DNA they may contain. The initial 40-50 s are needed to inactivate/break cells and release the DNA out of the cells, plus another extra time to observe a degradation of the DNA and decay of its PCR ability (i.e., its potential to be biologically re-used and genomically integrated by microorganisms).

In contrast, the glutaraldehyde treatments did not affect the amplification capacity of pure $\lambda$ DNA (Figure 6C). An ANOVA on these scores did not yield significant variation among the different concentrations of glutaraldehyde when compared with the control $(F=0.70, p>0.658$, Supplementary Table S4), supporting the results obtained from the DNA fragmentation experiments (Figure 5C). No significant effect on amplification ability was observed when a standard incubation time of $20 \mathrm{~min}$ was applied. Glutaraldehyde damages DNA (Hopwood, 1975) and compromises the PCR ability of DNA after some days of incubation only (Das et al., 2014). In clinical procedures, an exposure of $20 \mathrm{~min}$ at $20^{\circ} \mathrm{C}$ in a $2 \% \mathrm{w} / \mathrm{w}$ glutaraldehyde solution is solely used to disinfect medical instruments (Park et al., 2013). We showed that this short incubation time of 20 min was not enough to impact the integrity and PCR ability of DNA. Overall, glutaraldehyde offers an efficient way to disinfect and contain DNA and xenogenic elements inside cells.

\section{Outlook}

Overall, all common sterilization methods here tested are effective to inactivate microorganisms, highlighting short incubation time of $20 \mathrm{~min}$ with glutaraldehyde for its capacity to avoid DNA release. In terms of DNA loss of integrity, autoclave is shown to be the most effective method. However, integrity of released DNA is not completely compromised as shown by qPCR results. This opens a window for improvement in case total extracellular DNA degradation was desired. Alternatives to standard procedures are combination of methods here tested or further steps toward total removal such as ethylene oxide that has been shown to reduce DNA amplification when long exposure times are applied (Shaw et al., 2008). Fragmented sequences as 
short as 20 bp have been shown to be taken up and incorporated into the bacterial DNA, including mammoth DNA (OverballePetersen et al., 2013). Even if the majority of short residual DNA fragments will be re-metabolized in case they are taken up, there is a probability to be genome integrated generating new diversity (Overballe-Petersen and Willerslev, 2014).

Horizontal gene transfer phenomena from sterilized cultures may exchange all kind of DNA fragments as soon as these enter microbiome hotspots such as wastewater treatment plants (Miller et al., 2016). New microbial diversity can be generated through gene transfer, but also undesirable fragments such as ARGs and pathogenic islands could be unfavorably mobilized by microorganisms (Jørgensen et al., 2014; Messerer et al., 2017). This underlies the ubiquity and potentiality of these DNA fragments generated after sterilizations. Further research on the quality and composition of released DNA as well as rates of horizontal gene transfer are necessary to develop risk assessments strategies and to address the impact of the standard sterilization methods on biosafety and environmental and public health.

\section{DATA AVAILABILITY STATEMENT}

All datasets generated for this study are included in the article/Supplementary Material.

\section{REFERENCES}

Akșen, F., Kaya, A., and Akpolat, N. (2004). Comparision of bactericidal activity of microwave, ultraviolet and disinfectant solutions on some bacterial strains. Biotechnol. Biotechnol. Equip. 18, 122-127. doi: 10.1080/13102818.2004. 10817098

Azeredo, J., Lazarova, V., and Oliveira, R. (1999). Methods to extract the exopolymeric matrix from biofilms: a comparative study. Water Sci. Technol. 39, 243-250. doi: 10.1016/S0273-1223(99)00174-2

Ballantyne, B., and Jordan, S. L. (2001). Toxicological, medical and industrial hygiene aspects of glutaraldehyde with particular reference to its biocidal use in cold sterilization procedures. J. Appl. Toxicol. 21, 131-151. doi: 10.1002/ jat.741

Belyaev, I. (2005). Nonthermal biological effects of microwaves: current knowledge, further perspective, and urgent needs. Electromagn. Biol. Med. 24, 375-403. doi: 10.1080/15368370500381844

Belyaev, I. Y., Alipov, Y. D., Shcheglov, V. S., and Lystsov, V. N. (1992). Resonance effect of microwaves on the genome conformational state of E. coli Cells. Z. Naturforsch.Sect. C J. Biosci. 47, 621-627. doi: 10.1515/znc-19927-822

Bergerová, E., Godálová, Z., and Siekel, P. (2011). Combined effects of temperature, pressure and low $\mathrm{pH}$ on the amplification of DNA of plant derived foods. Czech J. Food Sci. 29, 337-345. doi: 10.17221/217/2010-cjfs

Blattner, F. R., Plunkett, G., Bloch, C. A., Perna, N. T., Burland, V., Riley, M., et al. (1997). The complete genome sequence of Escherichia coli K-12. Science 277, 1453-1462. doi: 10.1126/science.277.5331.1453

Bouki, C., Venieri, D., and Diamadopoulos, E. (2013). Detection and fate of antibiotic resistant bacteria in wastewater treatment plants: a review. Ecotoxicol. Environ. Saf. 91, 1-9. doi: 10.1016/j.ecoenv.2013.01.016

Caleb, P., Gabriella, R., Shelby, S., Easparro, B., Atwood, J., and Nash, R. (2019). Evaluating the Impact of Bead Media Diameter and Material Composition. Kennesaw: Omni International, Inc, 1-18.

Das, K., Fernando, M. R., Basiaga, S., Wigginton, S. M., and Williams, T. (2014). Effects of a novel cell stabilizing reagent on DNA amplification by PCR as compared to traditional stabilizing reagents. Acta Histochem. 116, 55-60. doi: 10.1016/j.acthis.2013.05.002

\section{AUTHOR CONTRIBUTIONS}

DW, BA, and DC-F designed the study with inputs of QL and ML. DC-F and QL performed the experimental investigations. DC-F and DW wrote the manuscript with direct contribution, edits, and critical feedback by all authors.

\section{FUNDING}

This work is part of the research project "Transmission of Antimicrobial Resistance Genes and Engineered DNA from Transgenic Biosystems in Nature" (Targetbio) funded by the program Biotechnology and Safety (grant no. 15812) of the Applied and Engineering Sciences Division of the Dutch Research Council (NWO). This manuscript has been released as a Pre-Print at BioRxiv: https://doi.org/10.1101/ 833228.

\section{SUPPLEMENTARY MATERIAL}

The Supplementary Material for this article can be found online at: https://www.frontiersin.org/articles/10.3389/fbioe. 2020.00171/full\#supplementary-material

Debode, F., Janssen, E., and Berben, G. (2007). Physical degradation of genomic DNA of soybean flours does not impair relative quantification of its transgenic content. Eur. Food Res. Technol. 226, 273-280. doi: 10.1007/s00217-006-0536- 1

D’Souza, S. F., and Marolia, K. Z. (1999). Stabilization of Micrococcus lysodeikticus cells towards lysis by lysozyme using glutaraldehyde: application as a novel biospecific ligand for the purification of lysozyme. Biotechnol. Tech. 13, 375378. doi: 10.1023/A:1008979709047

Elhafi, G., Naylor, C. J., Savage, C. E., and Jones, R. C. (2004). Microwave or autoclave treatments destroy the infectivity of infectious bronchitis virus and avian pneumovirus but allow detection by reverse transcriptase-polymerase chain reaction. Avian Pathol. 33, 303-306. doi: 10.1080/0307945042000205874

Engel, S. R., Dietrich, F. S., Fisk, D. G., Binkley, G., Balakrishnan, R., Costanzo, M. C., et al. (2014). The reference genome sequence of saccharomyces cerevisiae?: then and now. Genes| Genomes| Genetics 4, 389-398. doi: 10.1534/ g3.113.008995

Espy, M. J., Uhl, J. R., Sloan, L. M., Rosenblatt, J. E., Cockerill, F. R., and Smith, T. F. (2002). Detection of vaccinia virus, herpes simplex virus, varicella-zoster virus, and Bacillus anthracis DNA by LightCycler polymerase chain reaction after autoclaving: implications for biosafety of bioterrorism agents. Mayo Clin. Proc. 77, 624-628. doi: 10.4065/77.7.624

Fang, Y., Hu, J., Xiong, S., and Zhao, S. (2011). Effect of low-dose microwave radiation on Aspergillus parasiticus. Food Control 22, 1078-1084. doi: 10.1016/ j.foodcont.2011.01.004

Ferriss, R. S. (1984). Effects of Microwave Oven Treatment on Microorganisms in Soil, Vol. 74. Lexington: University of Kentucky, 121-126.

Flores, M. V., Ertola, R. J. J., and Voget, C. E. (1996). Characterization of a glutaraldehyde stabilized yeast cell biocatalyst with $\beta$-galactosidase activity. J. Ferment. Bioeng. 81, 524-529. doi: 10.1016/0922-338X(96)81473-5

Gryson, N. (2010). Effect of food processing on plant DNA degradation and PCR-based GMO analysis: a review. Anal. Bioanal. Chem. 396, 2003-2022. doi: 10.1007/s00216-009-3343-2

Hopwood, D. (1975). The reactions of glutaraldehyde with nucleic acids. Histochem. J. 7, 267-276. doi: 10.1007/BF01003595

Jankovic, S., Milosev, M., and Novakovic, M. (2014). The effects of microwave radiation on microbial cultures. Hosp. Pharmacol. Int. Multidiscip. J. 1, 102-108. doi: 10.5937/hpimj1402102j 
Jørgensen, T. S., Kiil, A. S., Hansen, M. A., Sørensen, S. J., and Hansen, L. H. (2014). Current strategies for mobilome research. Front. Microbiol. 5:750. doi: 10.3389/fmicb.2014.00750

Kajiwara, S., Shirai, A., Fujii, T., Toguri, T., Nakamura, K., and Ohtaguchi, K. (1996). Polyunsaturated fatty acid biosynthesis in Saccharomyces cerevisiae: expression of ethanol tolerance and the FAD2 gene from Arabidopsis thaliana. Appl. Environ. Microbiol. 62, 4309-4313. doi: 10.1128/aem.62.12.4309-4313. 1996

Karni, M., Zidon, D., Polak, P., Zalevsky, Z., and Shefi, O. (2013). Thermal Degradation of DNA. DNA Cell Biol. 32, 298-301. doi: 10.1089/dna.2013.2056

Kim, S. Y., Jo, E. K., Kim, H. J., Bai, K., and Park, J. K. (2008). The effects of high-power microwaves on the ultrastructure of Bacillus subtilis. Lett. Appl. Microbiol. 47, 35-40. doi: 10.1111/j.1472-765X.2008.02384.x

Kloos, D. U., Stratz, M., Guttler, A., Steffan, R. J., and Timmis, K. N. (1994). Inducible cell lysis system for the study of natural transformation and environmental fate of DNA released by cell death. J. Bacteriol. 176, 7352-7361. doi: 10.1128/jb.176.23.7352-7361.1994

López-Andreo, M., Aldeguer, M., Guillén, I., Gabaldón, J. A., and Puyet, A. (2012). Detection and quantification of meat species by qPCR in heat-processed food containing highly fragmented DNA. Food Chem. 134, 518-523. doi: 10.1016/j. foodchem.2012.02.111

Maillard, J. Y. (2002). Bacterial target sites for biocide action. J. Appl. Microbiol. Symp. Suppl. 92, 16-27.

Maity, J. P., Chakraborty, S., Kar, S., Panja, S., Jean, J. S., Samal, A. C., et al. (2009). Effects of gamma irradiation on edible seed protein, amino acids and genomic DNA during sterilization. Food Chem. 114, 1237-1244. doi: 10.1016/j. foodchem.2008.11.001

Masser, A. E., Kandasamy, G., Mohanakrishnan, K. J., and Andreasson, C. (2016). Luciferase NanoLuc as a reporter for gene expression and protein levels in Saccharomyces cerevisiae. Yeast 33, 191-200. doi: 10.1002/yea

Masters, C. I., Miles, C. A., and Mackey, B. M. (1998). Survival and biological activity of heat damaged DNA. Lett. Appl. Microbiol. 27, 279-282. doi: 10.1046/ j.1472-765X.1998.00447.x

Messerer, M., Fischer, W., and Schubert, S. (2017). Investigation of horizontal gene transfer of pathogenicity islands in Escherichia coli using nextgeneration sequencing. PLoS One 12:e0179880. doi: 10.1371/journal.pone.017 9880

Michaelson, S. M. (1974). Effects of exposure to microwaves: problems and perspectives. Environ. Health Perspect. 8, 133-155. doi: 10.1289/ehp.748133

Miller, J. H., Novak, J. T., Knocke, W. R., and Pruden, A. (2016). Survival of antibiotic resistant bacteria and horizontal gene transfer control antibiotic resistance gene content in anaerobic digesters. Front. Microbiol. 7:263. doi: 10.3389/fmicb.2016.00263

Munton, T. J., and Russell, A. D. (1973). Effect of glutaraldehyde on cell viability, triphenyltetrazolium reduction, oxygen uptake, and $\beta$-galactosidase activity in Escherichia coli. Appl. Microbiol 26, 508-511. doi: 10.1128/aem.26.4.508-511. 1973

Okuda, K., Urabe, I., Yamada, Y., and Okada, H. (1991). Reaction of glutaraldehyde with amino and thiol compounds. J. Ferment. Bioeng. 100-105. doi: 10.1016/ 0922-338x(91)90231-5

Overballe-Petersen, S., Harms, K., Orlando, L. A. A., Moreno Mayar, J. V., Rasmussen, S., Dahl, T. W., et al. (2013). Bacterial natural transformation by highly fragmented and damaged DNA. Proc. Natl. Acad. Sci. U.S. A. 110, 19860-19865. doi: 10.1073/pnas. 1315278110

Overballe-Petersen, S., and Willerslev, E. (2014). Horizontal transfer of short and degraded DNA has evolutionary implications for microbes and eukaryotic sexual reproduction. BioEssays 36, 1005-1010. doi: 10.1002/bies.20140 0035

Park, S., Jang, J. Y., Koo, J. S., Park, J. B., Lim, Y. J., Hong, S. J., et al. (2013). A review of current disinfectants for gastrointestinal endoscopic reprocessing. Clin. Endosc. 46, 337-341. doi: 10.5946/ce.2013.46.4.337

R Foundation for Statistical Computing (2018). R: a Language and Environment for Statistical Computing. Vienna: R Foundation for Statistical Computing.
Sehmi, S. K., Allan, E., MacRobert, A. J., and Parkin, I. (2016). The bactericidal activity of glutaraldehyde-impregnated polyurethane. Microbiologyopen 5, 891897. doi: $10.1002 / \mathrm{mbo} 3.378$

Sharma, M., Eastridge, J., and Mudd, C. (2009). Effective household disinfection methods of kitchen sponges. Food Control 20, 310-313. doi: 10.1016/j.foodcont. 2008.05.020

Shaw, K., Sesardiæ, I., Bristol, N., Ames, C., Dagnall, K., Ellis, C., et al. (2008). Comparison of the effects of sterilisation techniques on subsequent DNA profiling. Int. J. Legal Med. 122, 29-33. doi: 10.1007/s00414-007-0159-5

Shimpoh, T., Hirata, Y., Ihara, S., Suzuki, N., Kinoshita, H., Hayakawa, Y., et al. (2017). Prevalence of pks-positive Escherichia coli in Japanese patients with or without colorectal cancer. Gut Pathog. 9, 1-8. doi: 10.1186/s13099-017-0185-x

Shokri, A., and Larsson, G. (2004). Characterisation of the Escherichia coli membrane structure and function during fedbatch cultivation. Microb. Cell Fact. 3, 1-12. doi: 10.1186/1475-2859-3-9

Silkie, S. S., Tolcher, M. P., and Nelson, K. L. (2008). Reagent decontamination to eliminate false-positives in Escherichia coli qPCR. J. Microbiol. Methods 72, 275-282. doi: 10.1016/j.mimet.2007.12.011

Simmon, K. E., Steadman, D. D., Durkin, S., Baldwin, A., Jeffrey, W. H., Sheridan, P., et al. (2004). Autoclave method for rapid preparation of bacterial PCRtemplate DNA. J. Microbiol. Methods 56, 143-149. doi: 10.1016/j.mimet.2003. 10.003

Takeshi, O., Fumihiro, A., Hiroshi, A., Yukihiro, G., and Yoshihiro, O. (2003). Fragmentation of DNAs of processed foods made from genetically modified soybeans. Japanese J. Food Chem. 10, 155-160.

Teste, M. A., Duquenne, M., François, J. M., and Parrou, J. L. (2009). Validation of reference genes for quantitative expression analysis by real-time RT-PCR in Saccharomyces cerevisiae. BMC Mol. Biol. 10:99. doi: 10.1186/1471-2199-10-99

Tomasiewicz, D. M., Hotchkiss, D. K., Reinbold, G. W., Read, R. B., and Hartman, P. A. (1979). The Most Suitable Number of Colonies on Plates for Counting. J. Food Prot. 43, 282-286. doi: 10.4315/0362-028x-43.4.282

Trevors, J. T. (1996). ofMicrobiological methods sterilization and inhibition of microbial activity in soil. J. Microbiol. Methods 26, 53-59. doi: 10.1016/j. chemosphere.2017.09.011

Uemura, H. (2012). Synthesis and production of unsaturated and polyunsaturated fatty acids in yeast: current state and perspectives. Appl. Microbiol. Biotechnol. 95, 1-12. doi: 10.1007/s00253-012-4105-1

Woo, I. S., Rhee, I. K., and Park, H. D. (2000). Differential damage in bacterial cells by microwave radiation on the basis of cell wall structure. Appl. Environ. Microbiol. 66, 2243-2247. doi: 10.1128/AEM.66.5.2243-2247.2000

Wu, R. (1972). Nucleotide sequence analysis of DNA. Nat. New Biol. 236, 198-200. doi: 10.1038/newbio236198a0

Yang, Y., and Hang, J. (2013). Fragmentation of genomic DNA using microwave irradiation. J. Biomol. Tech. 24, 98-103. doi: 10.7171/jbt.13-2402-005

Yap, J. M., Goldsmith, C. E., and Moore, J. E. (2013). Integrity of bacterial genomic DNA after autoclaving: possible implications for horizontal gene transfer and clinical waste management. J. Hosp. Infect. 83, 247-249. doi: 10.1016/j.jhin. 2012.11.016

Zeng, S. W., Huang, Q. L., and Zhao, S. M. (2014). Effects of microwave irradiation dose and time on Yeast ZSM-001 growth and cell membrane permeability. Food Control 46, 360-367. doi: 10.1016/j.foodcont.2014.05.053

Conflict of Interest: The authors declare that the research was conducted in the absence of any commercial or financial relationships that could be construed as a potential conflict of interest.

Copyright (C) 2020 Calderón-Franco, Lin, van Loosdrecht, Abbas and Weissbrodt. This is an open-access article distributed under the terms of the Creative Commons Attribution License (CC BY). The use, distribution or reproduction in other forums is permitted, provided the original author(s) and the copyright owner(s) are credited and that the original publication in this journal is cited, in accordance with accepted academic practice. No use, distribution or reproduction is permitted which does not comply with these terms. 